\title{
All You Can Do Is Love It: As You Like It Meets the Bards of Liverpool
}

\section{by Melissa Walter and Emily Warwick. Published in 2018 Issue 1.}

For the production: As You Like It (2018, BMO Main Stage, Bard on the Beach). Performance attended: 2018-06-12. See production details at the end of the review.

ALthough A HipPIE-STYLE As You LiKe IT IS NOT NEWS, BARD ON THE BEACH'S 2018 PRODUCTION OFFERed its own fun interpretation. Director Daryl Cloran cut about half of the original text and incorporated 25 songs by The Beatles, from "We all Live in a Yellow Submarine" to "Helter Skelter" to, of course, "All You Need is Love" (see Bard's playlist on Spotify). In some ways an answer to or development of Bard's earlier Merry Wives of Windsor (Ontario) in 2016, the show took a cue from Bard on the Beach's location "in Kitsilano-home of Vancouver's counterculture," according to Cloran. It was set initially in Vancouver in the 1960s, with the forest as the wild "Oak"anagan (wordplay that references British Columbia's Okanagan Valley region), and drew on the 1960sVancouver institution of All-Star Wrestling. The second half of the play, which shifted into 1970s fashion and culture, was largely replaced with Beatles songs, and sometimes there was a loss of narrative coherence. In 4.1, one of the few times where Rosalind/Ganymede and Orlando are interacting one-on-one, TLN 1961-2030 (approximately) was cut. The songs seemed a thin substitute for the witty dialogue in this scene. But the songs were so much fun-with brilliant musical arrangements by Artistic Associate Ben Elliott (who also arranged the music for Bard's Merry Wives) - and so vividly and beautifully performed by the band, that all you could do was love it.

A wrestling "pre-show" - during which the central stage was taken up by a large wrestling matinvited audience participation even before the play actually began. Reigning champion Mustachio, cheered on by his girlfriend, Eleanor Rigby (later Phoebe, both played by Luisa Jojic), handily defeated the Assassins (coached by "their mom, trainer, coach, and previous champion"-later the gender-role-inverting Audrey [Emma Slipp]), and was in turn defeated by Charles. Anticipating Phoebe's later defection to Ganymede, Eleanor Rigby left Mustachio for Charles. Early in the play's run, the audience unfortunately didn't seem too aware of wrestling show protocol, and therefore few offered either cheering or jeering. Still, it was a lively beginning. As the season continued and the production received rave reviews (and an extended run 
into September), audiences knew to arrive early and participate. ${ }^{1}$

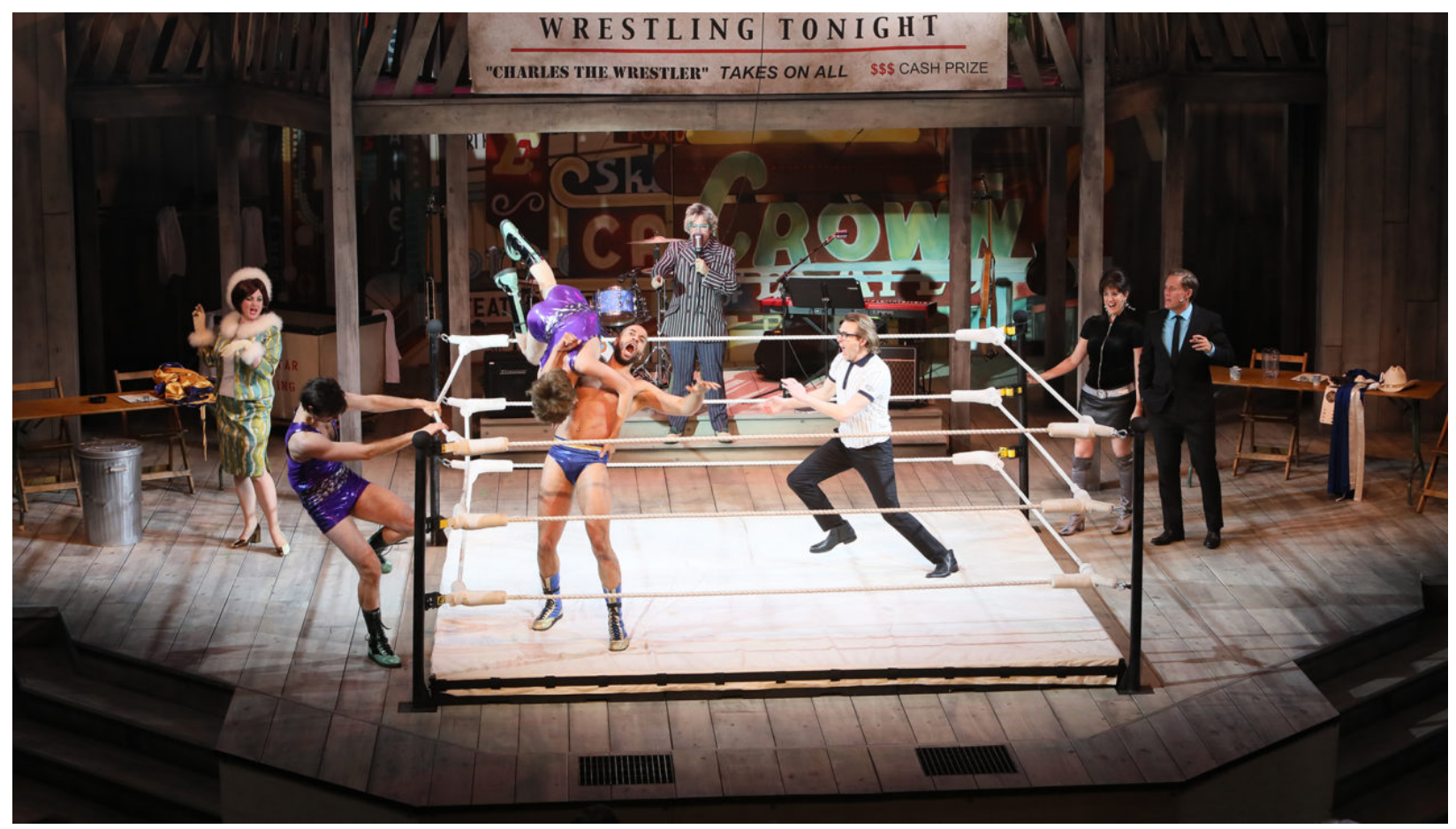

Figure 1. Austin Eckert as Charles the Wrestler in the pre-show. Photo Credit: Tim Matheson. Courtesy of Bard on the Beach.

The show proper began with Touchstone making various announcements, among which was his ironic advice to noisy playgoers, possibly intent on opening crinkly wrappers, to wait for the quietest moment in the play and open their candy as slowly as possible. After the announcements came "We All Live in a Yellow Submarine." On the June evening when we saw the show, it was raining and the light was actually yellow. A sense of community and bonding was created by the fact that many people are able to sing along with that song. One of the most kid-friendly of The Beatles' songs, the song brings out an audience's childlike or adolescent qualities, setting a tone of nostalgia, empathy, and play. And yes-we do all live in a yellow submarine, fragile and limited and yet cheerfully so, bathed in the wet lemon light of a pacific northwest dusk.

Charles the Wrester (Austin Eckert-who also played, later, the guitarist and Amiens, with voluminous hair and pink flowered pants, but here was sleek in his wrestling shorts) had already defeated several challengers in the preshow. The wrestling match between Charles and Orlando (Nadeem Phillip, in high-waisted shorts that somehow made the young challenger look all the

\footnotetext{
${ }^{1}$ The connection to All-Star Wrestling could have been made even more overt by naming Canadian wrestler Gene Kininski, who rose to fame in the professional wrestling industry in the 1960 s and still has a tavern named after him in Point Roberts, Kininski's Reef, now owned and operated by his sons. A poster would have added a small but pertinent historical detail to the setting and more firmly connected the change of setting from the Forest of Arden to Vancouver.
} 
more earnest) was choreographed to coordinate the musical rhythms with a slow-motion effect and alluring purple lighting that gave the sense of reeling from blows-and yet also falling in love-all in suspended time. The staging presented starstruck, awe-inspiring love between Orlando and Rosalind with lighting and music.

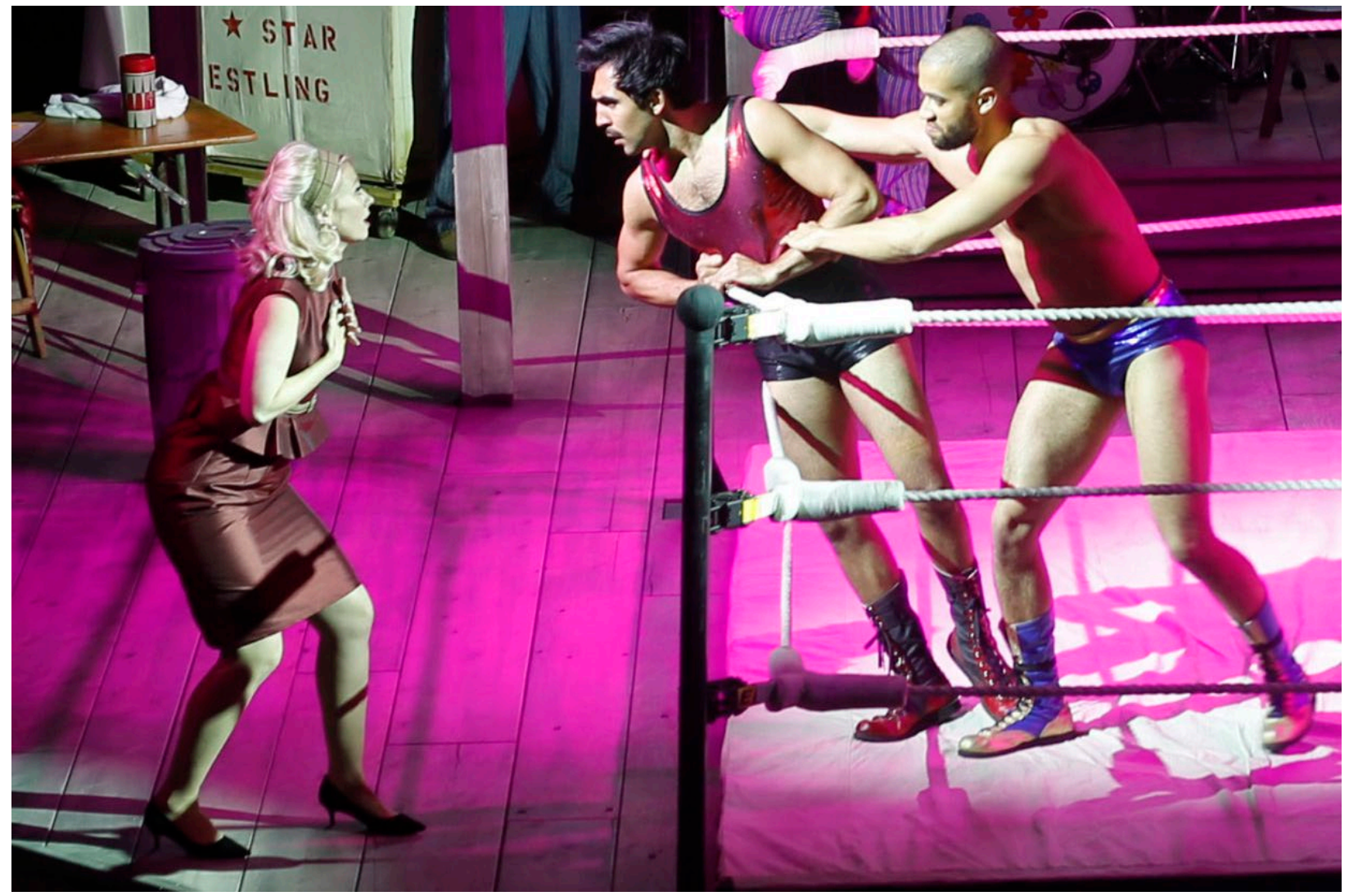

Figure 2. Lindsey Angell as Rosalind falls for Nadeem Phillip as Orlando. Photo Credit: Tim Matheson. Courtesy of Bard on the Beach.

Phillip's performance as Orlando was extremely charming, beginning with his hapless reeling and wide love-struck eyes in the wrestling match and continuing throughout. A brilliant dancer and singer and eminently persuasive leading man, he portrayed a plucky, energetic, optimistic character who was determined to make his way, and who loved and wooed Rosalind/Ganymede (Lindsay Angell) with winning devotion and resolve.

Rosalind was similarly brilliant in her role. She is utterly persuasive dramatically, a great singer and a centered and lively dancer. As Colin Thomas points out in his theatre blog, though, the decision to make Rosalind reinforce the gender binary by remaining clearly feminine and nonpassing while dressed as Ganymede (in an electric blue pantsuit with a pink shirt) misses out on some of the potentialities of this character. 


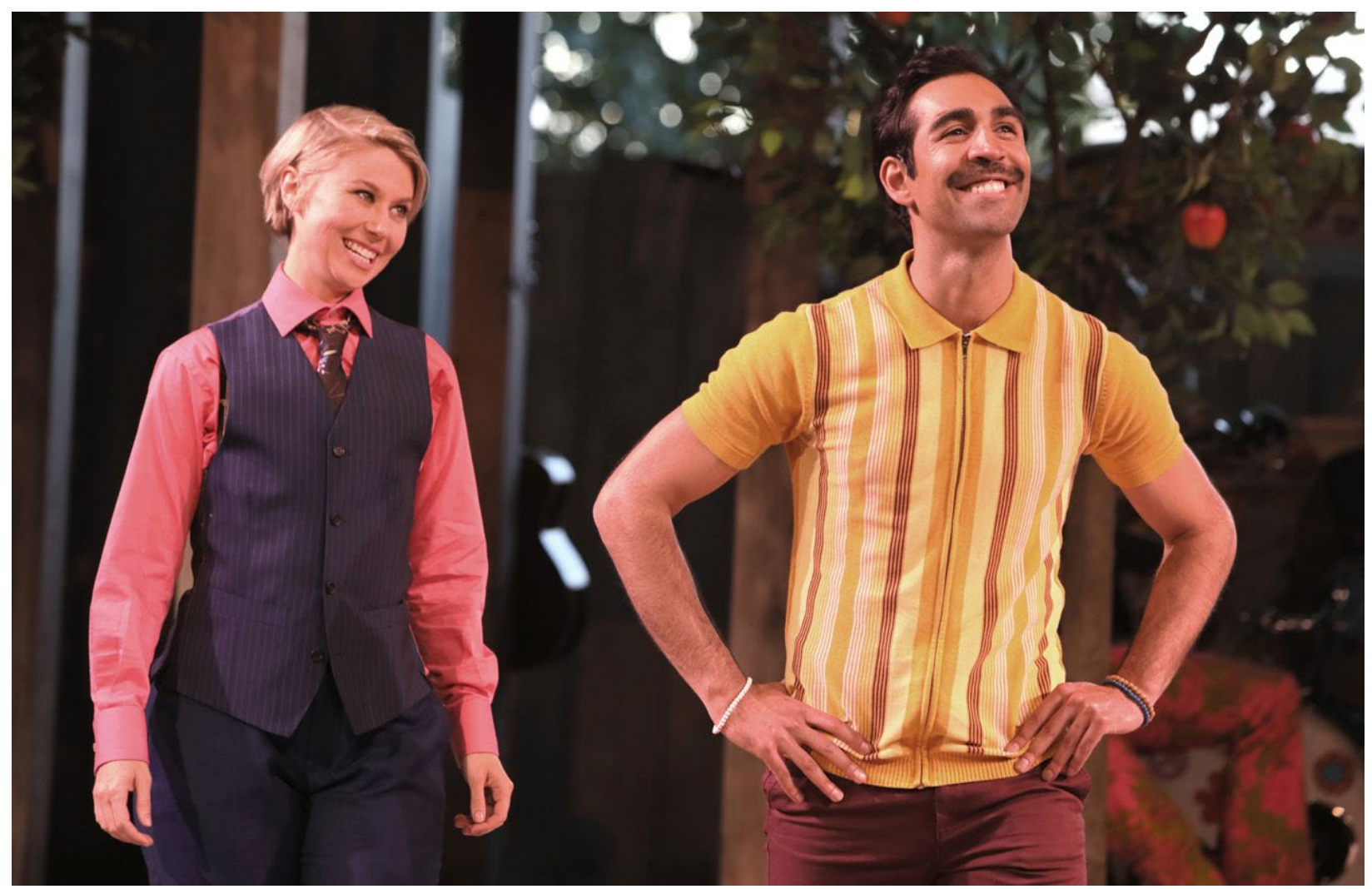

Figure 3. Lindsey Angell as Rosalind/Canymede with Nadeem Phillip as Orlando. Photo Credit: Tim Matheson. Courtesy of Bard on the Beach.

Scott Bellis played both Dukes. To hear Duke Senior's opening words in the forest ("Now, my comates and brothers in exile / Is not this life more sweet than painted pomp") delivered by a Bellis wearing clogs, a green-on-khaki floral print tunic, and wooden beads was somehow deeply and warmly ridiculous. Carmen Alatorres's costumes, brilliant throughout, were especially so in the forest, where their wild colours and inventive John Fluevog shoes (a brand born in 1970s Vancouver) added to the feeling of playful expressiveness. It was not the first time that, for an $A s$ You Like It set in the 1960s-1970s, play trumped politics. ${ }^{2}$ As with many other productions, this Bard on the Beach show was all about escaping into a pastoral landscape and revelling in love, without highlighting other features of the 1960 s and 1970s, such as anti-war/anti-imperial activism, the civil rights movement in the US, feminism, or quests for economic equality, that would bring wider access to opportunities for realizing human potential. Instead, this As You Like It celebrated the style and creativity of these decades.

Admittedly, there is a tendency in looking back to treat the 1960s-1970s as a playground, filled with fashion and fun, while forgetting about the continued need to work for fairness and against

\footnotetext{
${ }^{2}$ See, for instance, reviews of a 2015 performance by Seattle's Wooden O Theatre (Walter) and of a 2005 production at the Stratford Festival directed by Antonio Cimolini (Ouzounian).
} 
violence. What remained in the case of this As You Like It was an exuberant love song to a particular idea of 1970s Vancouver-to the crunchy-granola left coast. Interestingly, this view of the area will again be reinforced and playfully mocked when a version of the same conception is remounted by The Citadel Theatre in February-March 2020 in wintry Manitoba.

As in Bard's Merry Wives, beatnik-style spoken word was a source of humour in As You Like It. Jaques (Ben Carlson), dressed in an orange turtleneck and brown pants, soberly declaimed that "I am he, as you are he, as you are me, and we are all together," before Eckert's satisfying guitar and the rest of the band came in to play "I am the Walrus." Carlson continued holding forth, with increasingly wild gestures, and the effect was very funny. In contrast, his serious delivery of "All the world's a stage" was moving.

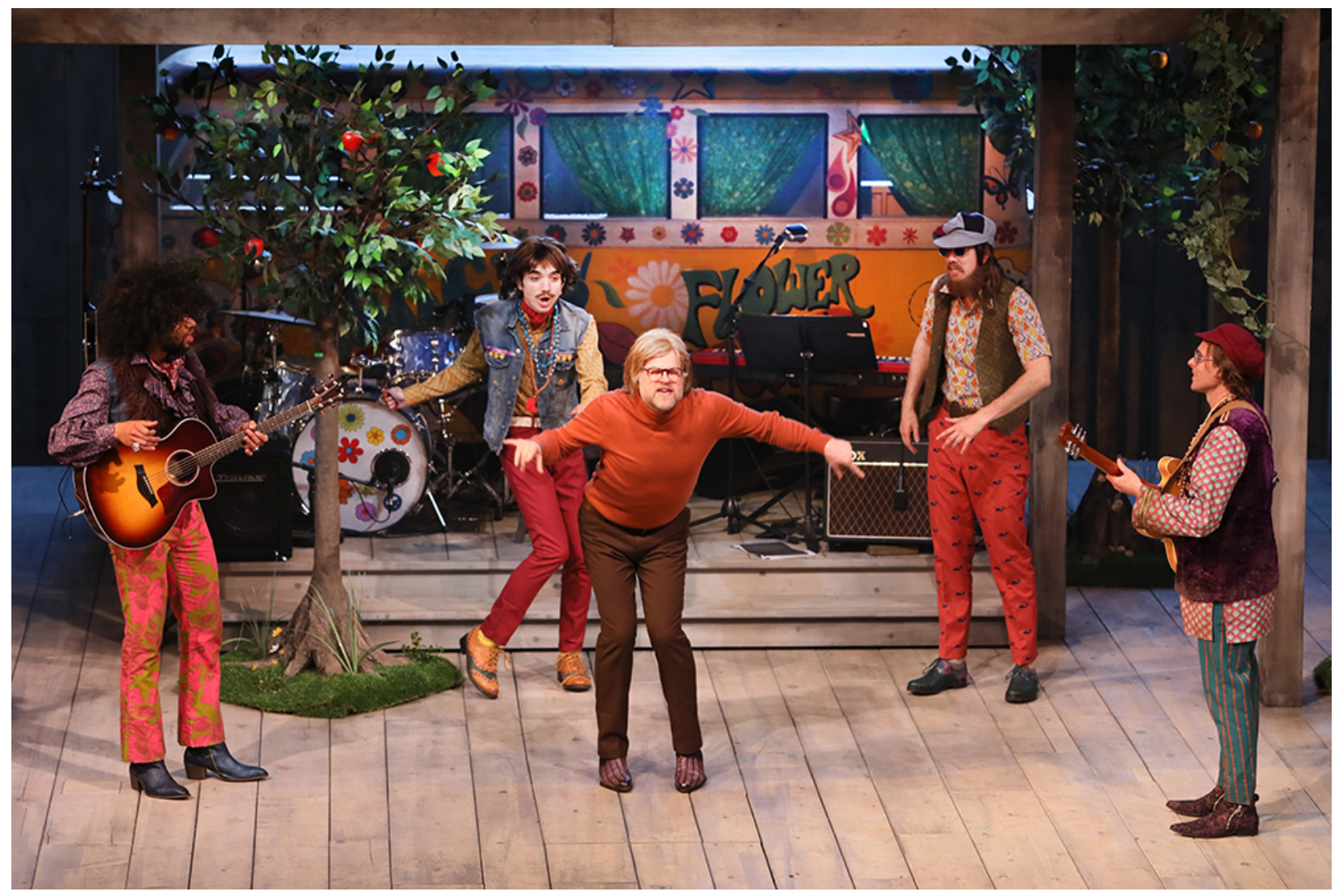

Figure 4. Ben Carlson as Jaques. Photo Credit: Tim Matheson. Courtesy of Bard on the Beach.

The music also included some gorgeously peaceful and reflective moments. Jeff Gladstone sang "Let It Be" to Adam as the old servant recovered in the forest. A later emotional shift-something akin to the resolution of grief, expressing the kind of quiet compassion for others that can spring forth from our darkest hours, and here expressing the healing influence of the benevolent forest and its friendly community—happened around the song "Here Comes the Sun." Such musical 
guidance provided some compensation for the speeches that typically provide the narrative coherence in the second act.

Touchstone (Kayvon Khoshkam), wearing pink glasses reminiscent of Elton John, kept having to swat away bees. When he scared off William by singing "Helter Skelter," he puffed himself up like a child pretending to be a bear and roared. Once he and Audrey (Emma Slipp) got to courting, one of their activities was to trade animal noises and gestures on hands and knees: a frog's ribbet, an elephant's trumpeting trunk. They ended the play "rocking out," as it were, in the VW van at the back of the set.

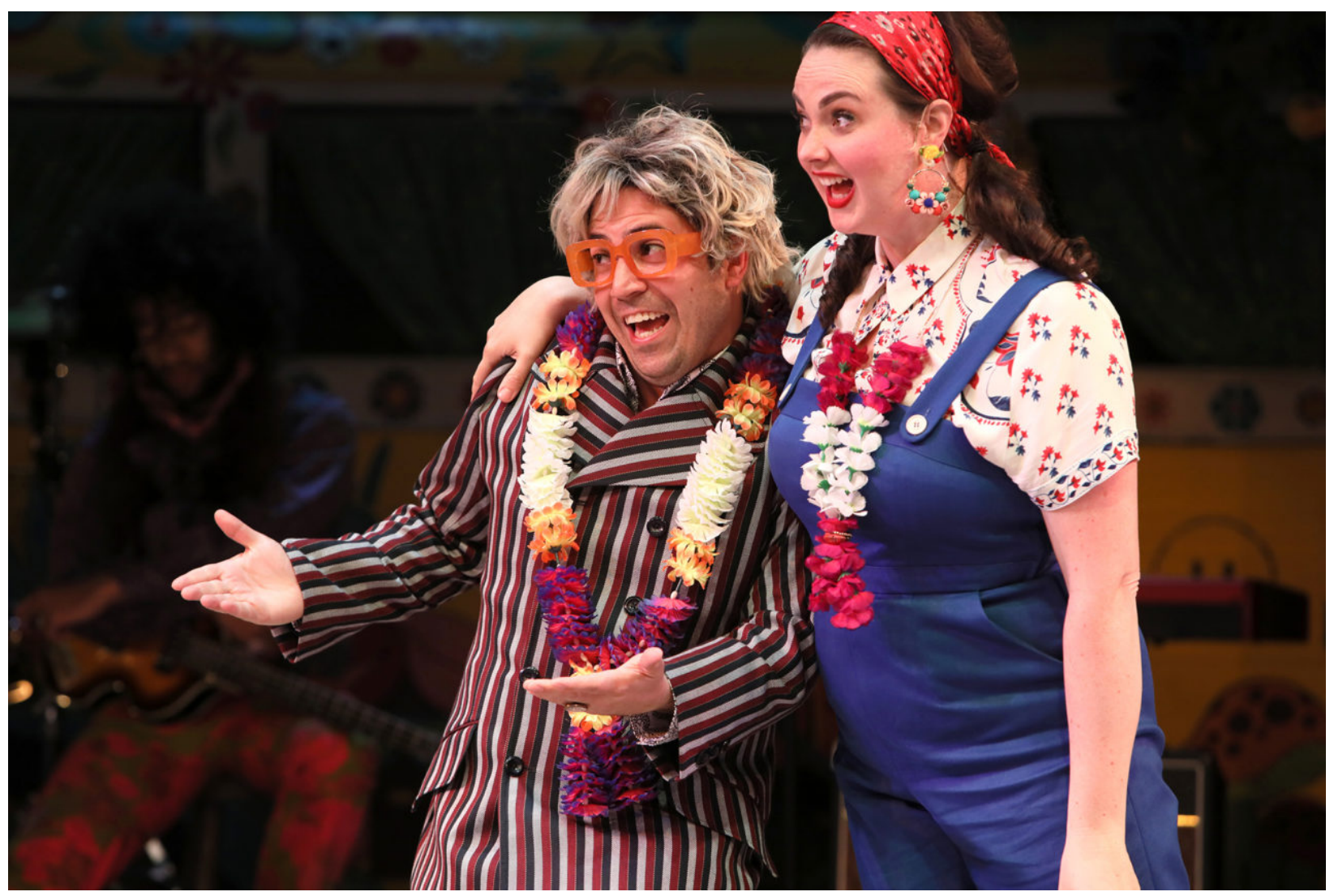

Figure 5. Kayvon Khoshkam as Touchstone with Emma Slipp as Audrey. Photo Credit: Tim Matheson. Courtesy of Bard on the Beach.

Luisa Jojic was magnificent as the cruel and hilarious Phoebe. In her Janis Joplin-type outfit of striped jeans and multicoloured headband, she stomped all over her lover, Silvius (Ben Elliott), while belting out "Something in the Way He Moves" (about Ganymede). Her own jerky and unstable movements, as well as those of the pummeled Silvius, added a layer of humour to the song's lyrics. Her own energy and emphases were not just funny but also impressive.

Elliott threw his long limbs into it as he sang "I Saw Her Standing There" of scornful Phoebe, then rattled to the piano for a solo. Elliot, the earnest, goofy, devoted, put-upon, and faithful lover, a 
quite brilliant physical comedian, was also the pianist and musical director. All the band members stepped in and out of character as necessary to play various parts in the play and various instruments in the band, but watching Elliot make the transition from hapless, (ab)used lover to brilliant keyboardist and conductor was particularly enjoyable. The fact that the actor who plays the ultimately rewarded, abject devotee also masterminds the music that everyone enjoys so much in the show extends the joke somehow-and the joke may be on the audience, but we don't care, because we are having such a good time.

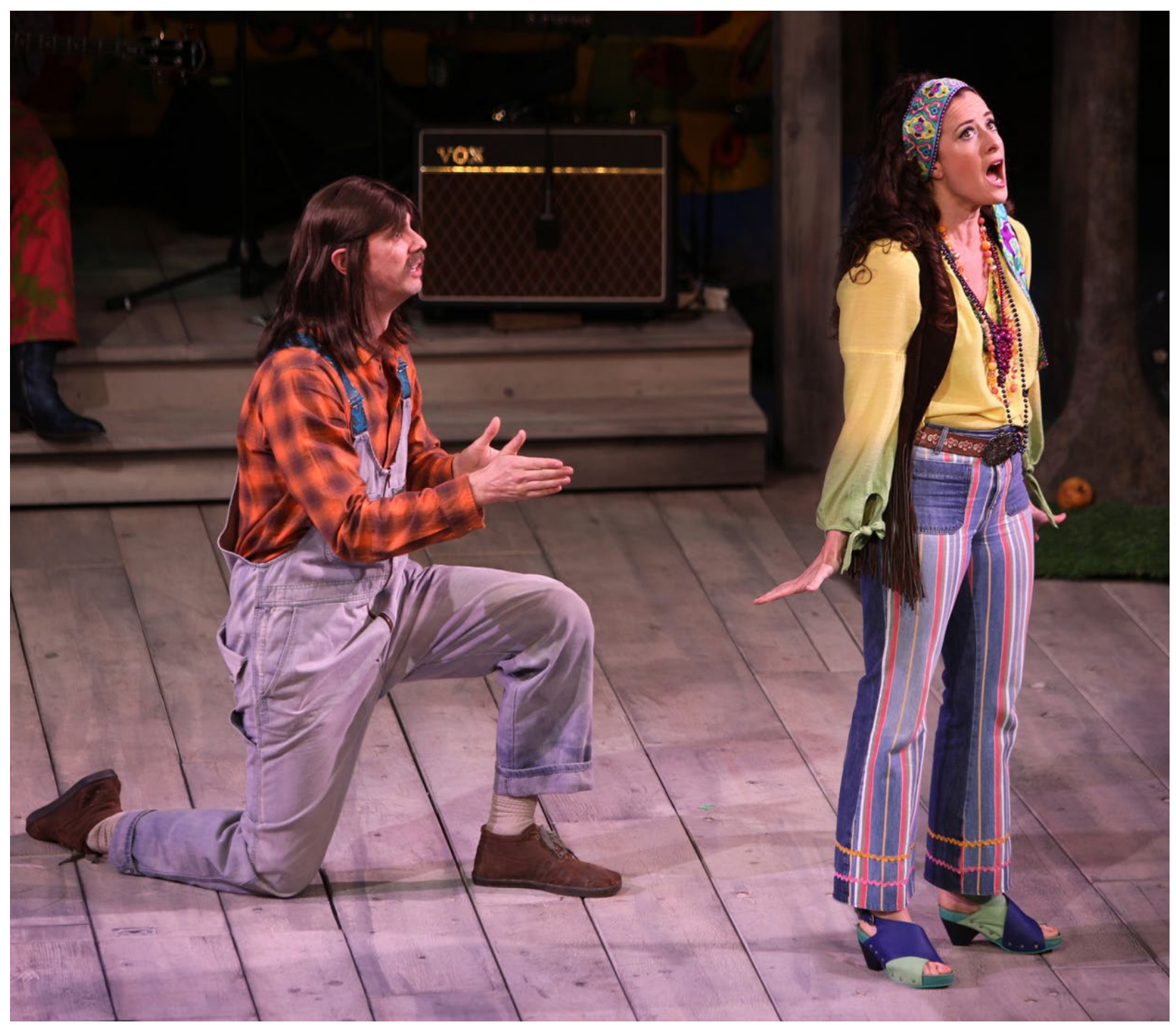

Figure 6.Ben Elliott as Silvius woos Luisa Jojic as the scornful Phoebe. Photo Credit: Tim Matheson. Courtesy of Bard on the Beach. 


\section{References}

Ouzounian, Richard. “As You Like It.” Variety, June 13, 2005.

https://variety.com/2005/legit/reviews/as-you-like-it-14-1200525196/.

Thomas, Colin. "As You Like It: You'll Love It." Colin Thomas/Substantive Editor, June 23, 2018. https://colinthomas.ca/2018/06/23/as-you-like-it.

Walter, Melissa. “Wooden O's As You Like It: Shakespeare Speaks for Self-Actualization in Northwest Forest." Scene: Reviews of Early Modern Drama, vol. 2, no. 1, 2017. DOI: 10.18357/sceneo1201718454.

\section{Links}

Bard on the Beach. https://bardonthebeach.org/

Bard on the Beach Spotify Playlist.

https://open.spotify.com/playlist/IWNKCLaGJzW6JjRBV3jBLD?si=HPaT_AfpQoGZOdv2G7 wJ2wX

The Citadel Theatre. https:/www.citadeltheatre.com/2019-2020/as-you-like-it

Matheson, Tim. Production photos for As You Like It. https://bardonthebeach.org/news/2018/asyou-like-it-the-story-in-photos/ 


\section{Production Details}

\section{General}

Title

Year

Theater Company

Theater

Start Date

End Date
As You Like It

2018

Bard on the Beach

BMO Main Stage

2018-06-12

2019-09-23

\section{Cast}

ORLANDO DE BOYS
ADAM
OLIVER DE BOYS
CHARLES THE WRESTLER
CELIA
ROSALIND
DUKE FREDERICK
LE BEAU
TOUCHSTONE
DUKE FREDERICK'S ATTENDANT
DUKE SENIOR
AMIENS
FIRST LORD
SECOND LORD
CORIN
SILVIUS
JAQUES
AUDREY
SIR OLIVER MARTEXT
PHOEBE
WILLIAM
JACQUES DE BOYS
HYMEN

NADEEM PHILLIP

ANDREW WHEELER

CRAIG ERICKSON

AUSTIN ECKERT

HARVEEN SANDHU

LINDSEY ANGELL

SCOTT BELLIS

JEFF GLADSTONE

KAYVON KHOSHKAM

SHARON CRANDALL

SCOTT BELLIS

AUSTIN ECKERT

JEFF GLADSTONE

NiCCO DEL RIO

SHARON CRANDALL

BEN ELLIOTT

BEN CARLSON

EMMA SLIPP

ANDREW WHEELER

LUISA JOJIC

NICCO DEL RIO

NICCO DEL RIO

JEFF GLADSTONE 


\section{Creatives}

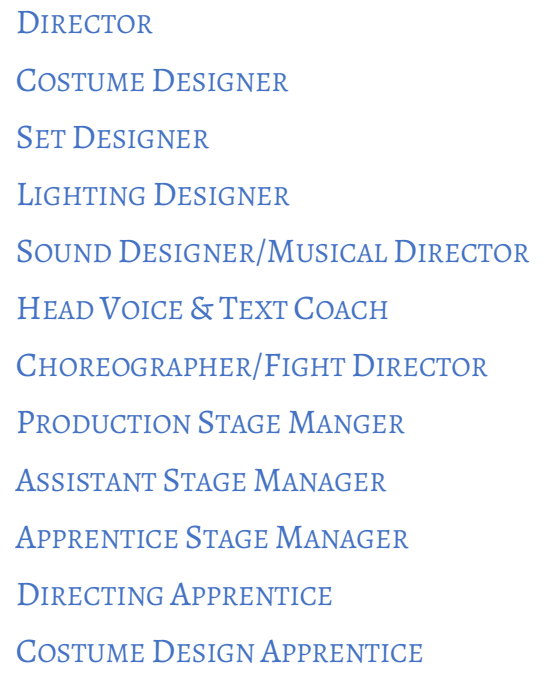

DARYL CLORAN

CARMEN AlatorRe

PAM JOHNSON

GERALD KING

BEN ELLIOTT

Alison MatTHEWS

Jonathan HaWley PuRvis

STEPHEN COURTENAY

REBECCA MULVIHILL

JENNY KiM

KIM SENKLIP HARVEY

EMILY FRASER 